\title{
Consumerscapes and the resilience assessment of urban retail systems
}

\author{
Herculano Cachinho* \\ IGOT, University of Lisbon, Portugal
}

\section{A R T I C L E I N F O}

\section{Article history:}

Available online 22 November 2012

\section{Keywords:}

Retail resilience

Consumerscapes

Consumer culture theory (CCT)

Consumer satisfaction

Urban retail system

Retail strategy

\begin{abstract}
A B S T R A C T
Despite the plethora of studies on the behavior and values of consumers, research in the social sciences tends to sideline the role of the cultural dimension of consumption in the assessment of vitality and resilience of urban retail systems. However, given the tendency for retailers to make consumers a key element in their strategies, the cultural approach seems to be a valuable alternative to firm-centric analysis. This paper seeks to face this challenge mobilizing the lens of Consumer Culture Theory (CCT). The aim is to show why consumerscapes matter in the assessment of urban retail resilience. According to Arnould (2005), CCT allows us to capture the motivating social and cultural contexts of retail patronage and purchasing behaviors and the myriad of motivating factors behind the retail purchase decision. People have a variety of projects that they tend to realize through shopping practices and consumption, and retailers offer the range of resources they need to accomplish such projects. Bearing these ideas in mind, we suggest that in order to assess the resilience of urban retailing we need to know the extent to which the different shopping districts provide consumers with the range of resources they want so as to fulfill their projects, and how retailers and public authorities can, in the long term, sustain or improve the levels of consumer satisfaction. These ideas are discussed both in a theoretical and empirical way supported by the data collected from consumer surveys carried out in three neighborhood shopping districts in Greater Lisbon.
\end{abstract}

(c) 2012 Elsevier Ltd. All rights reserved.

\section{Introduction}

Change has always shaped urban retail, and supply and demand have been its main architects. Consumers are constantly renewing their needs, wants and desires, changing their behaviors and lifestyles, with direct consequences on shopping activities. For their part, in order to survive and grow in a highly competitive environment, shopkeepers have to renew their strategies, introducing new retail concepts, innovative shopping environments and different types of goods and services (Borchert, 1998). In recent decades, these changes have not only intensified their pace but also broadened their scope, creating serious imbalances in the structure and spatial organization of the urban retail systems. Often, these shifts challenge the viability of retail facilities and jeopardize the sustainability of cities. The decline of small businesses at the expense of large corporations, the weakened role of the city centre over the suburbs, the disappearance of neighborhood stores in contrast to the growth of out-of-town mega-projects, and the devaluation of utilitarian premises in favor of the "spectacular" shopping spaces

\footnotetext{
* Address: Centro de Estudos Geográficos, edifício da Faculdade de Letras, Alameda da Universidade, 1600-214 Lisboa, Portugal. Tel.: +351 2179402 18; fax: +351217938690.

E-mail address: hc@campus.ul.pt
}

are now common features shared by cities with different positions in the urban hierarchy (Urban-Net, 2010).

Since retailing and consumption are key elements of the urban fabric and essential to the experience of the contemporary city (Clarke, 2003; Jayne, 2006; Miles, 2010), urban sustainability has been associated with the preservation of balanced and cohesive retail systems set up in a great diversity of facilities, shopping environments and places (ODPM, 2005, 2009; Goodman \& Coote, 2007; Guy, 2007). Similarly, urban retail resilience has been defined as the ability of stores and shopping districts to tolerate and adapt to changing environments that challenge the retail system's equilibrium, without failing to perform its functions in a sustainable way (Barata-Salgueiro, 2011; Wrigley \& Dolega, 2011). In this sense, urban retail systems can be considered resilient if, in a changing environment, the network of shopping districts is capable of retaining its economic viability, thus responding efficiently to the needs of different consumer groups, including the most disadvantaged, which are constrained to use the local and neighborhood retail/service facilities.

Envisaged in these terms, the preservation of urban sustainability and the resilience of retail systems are closely linked with the mechanisms of supply and demand mediated by socio-spatial contexts. In this article we will discuss the role of demand. Looking at shoppers through the lens of the consumer culture theory 
(Arnould, 2005; Arnould \& Thompson, 2005) and the resourcebased theory (Vargo \& Lusch, 2004), we intend to show why consumerscapes matter when we seek to assess and foster the resilience of urban retailing systems. According to Arnould (2005, p. 89), the Consumer Culture Theory (CCT) allows us to capture the motivating social and cultural contexts of retail patronage and purchase behaviors and the myriad of motivating factors behind the retail purchase decision. People have a variety of projects that they tend to achieve through shopping, and retailers offer the range of resources they need to accomplish such projects. Bearing these ideas in mind, we suggest here that in order to assess retail resilience it is crucial to know the extent to which the tenant mix of shopping districts provide consumers with the resources they need to carry out their projects and, on the other hand, if retailers and city authorities have the knowledge and skills suitable to keep or improve the levels of consumer satisfaction in the long term.

In short, in this article we will sketch a consumer-centric research approach in reply to the question of the resilience of urban retail. Although answers to the questions raised by the linkage between the perception of stores as fields of resources and the resilience of shopping districts still remain unclear, we hope that this discussion will shed more light on them. We shall therefore start by describing the main changes in urban retailing and how consumers have become the driving force behind these changes. We will then move onto a brief description of the CCT and its potential for the evaluation of trends in urban retailing. Finally we will extend the CCT to the resilience assessment of retailing systems. The discussion is conducted both in a theoretical and empirical way, supporting our arguments in the data gathered from consumer surveys carried out in three shopping districts in Greater Lisbon.

\section{Urban retail dynamics: from spaces for shopping to places of consuming experiences}

Retailing has always been an urban activity par excellence. The requirements of centrality and accessibility are the main factors responsible for this pattern of location. It was so in the past, it still is nowadays, and despite the potential of e-commerce it is likely to remain so in the near future. In fact, when there is a dearth of customers as happens in villages and small towns, retail shops tend to disappear or curtail their activity to cover only the barest essentials in offering low order goods and services. Other businesses earning their living on the sale of high order goods seldom last long in these places. Instead, every so often, "roving shops", which are vans belonging to the modern-day travelling salesman, make their rounds, and fairs become "temporary malls" held on different days of the week and in different places.

Nevertheless, the relationship between retail and city development at the present time has very little in common with that of bygone days. Over the past 50 years, changes in this field have been so vast and deep that most cities in the developed world have experienced a retail revolution (Bromley \& Thomas, 1993; Gardner \& Sheppard, 1989; Messerlin, 1982). Table 1 provides an overview of the most significant changes shaping the urban retail systems. Despite the differences that can be observed among the urban settings of different countries and cultures, the impacts of this revolution are everywhere. They are present in the tenant mix, in the spatial organization of the system, in the meaning of the premises or in the way people live, experience and relate to the city through consumption and shopping practices.

Firstly, in a short period of time, retailing has moved from being a dull business-backwater to become one of the most dynamic sectors of the urban economy. Due to the ever-changing array of goods and services, and the fascinating environments in which to buy them, for many people, shopping is no longer a basic activity to satisfy consumer needs; it has become a pleasurable 'leisure experience' in itself (Gardner \& Sheppard, 1989; Lipovetsky, 2006; Miles, 2010). In some way, it can be said that the retail revolution has transformed the consumer society and shopping places into a culture of consumption (Morace, 1990).

Secondly, this revolution has had an irreversible impact on the spatial organization of the urban retail systems. The secular marriage of retailing with centrality and proximity, which are the basic principles of the hierarchical system of shopping centers, was followed by convenience linkages offered by car accessibility, circulation and parking facilities. More recently, the assets of psycho-distances and mindscapes are now being explored by a wide variety of retail premises, spots and urban sites designed, marketed and publicized to evoke particular feelings or emotions, favoring their appropriation as spaces of leisure, conviviality, happiness and other virtues highly valued by the mass consumer society.

Spatially, this process involves the decentralization of retailing and fragmentation of the urban space has resulted in a significant weakening of the role of downtown and traditional neighborhood centers (Ravenscroft, 2000; Tallon, 2010). In postmodern times, shopkeepers' interests have turned to the city outskirts. With land prices that are cheaper and less coercive or, at least, more flexible regulations regarding the change of land use and the location of new premises, retail developers find the suburbs and urban edges more attractive to their businesses (Cachinho, 2011). This explains why over the past 30 years many retail developments have been set up in these places. At the same time, a wide variety of intraurban sites, hitherto devalued by retail capital, like waterfronts, brownfields and historical districts are being rediscovered, and the mix of entertainment with retailing is transforming them into hot spots, cool spaces and brand lands geared to consumer experiences.

Finally, a close look at the impacts produced by the retail revolution in the last few years show that we are gradually moving from a system based on "retail spaces" to another anchored in "consumer places", powered by the sign-value and symbolism of shopping environments and commodities (Cachinho, 2002). In fact, this passage summarizes the main metamorphoses undergone by retail spaces, thanks to marketing strategies and design geared to lure consumers. What we can identify during this period is a process whereby retail facilities have been transformed from sales points into commodities to be "consumed", in the same way that goods are sold and purchased inside them (Barata Salgueiro \& Cachinho, 2009). More than goods and services, they call upon consumers' life experiences (Coleman, 2006; Din, 2000; Hetzel, 2002; Mikunda, 2006; Pine \& Gilmore, 1999).

To sum up, regardless of urban socio-spatial contexts, the advent of the retail revolution has brought about a duality in retail spaces and shopping precincts in our cities. On the one hand, we find a large set of premises, which deprived of significant symbolic content for consumers, merely exchange money for goods and services and are poorly perceived as shopping spaces. On the other hand, we have a small group of facilities and environments that, by investing in the mise-en-scène of their commodities, in the architecture and design theatricality and in the simulation of built environment, explores the consumers' imagination and offer them authentic life experiences. In resorting to an old modern classification, while the former shops and environments satisfy simple needs which, at times, only exist in the minds of the retailers, the latter exploit hyper-reality, the capacity to create an illusion of their merchandise, and through these contrivances, sell the consumer dreams and desires. While the first group is in steep decline, undermining the vitality and the viability of the system, especially the neighborhoods deprived of physical and cultural amenities val- 
Table 1

Urban retail changes: from retail spaces to consumer places.

\begin{tabular}{|c|c|c|c|}
\hline Attributes & Modernity (until 50-60s) $\rightarrow$ & Post-modernity (70-90s) $\rightarrow$ & Hyper-modernity (after 90s) \\
\hline Kind of retail spaces & $\begin{array}{l}\text { Traditional stores owned by small } \\
\text { shopkeepers }\end{array}$ & $\begin{array}{l}\text { New retail concepts and formats owned by } \\
\text { multiples and big corporations }\end{array}$ & $\begin{array}{l}\text { Diversity of retail concepts and formats owned } \\
\text { by multiples and big firms }\end{array}$ \\
\hline Spatial organization & $\begin{array}{l}\text { Hierarchical structure dominated by the city } \\
\text { centre, based on centrality and proximity }\end{array}$ & $\begin{array}{l}\text { Centre-periphery dialectics based on } \\
\text { accessibility, circulation and parking } \\
\text { facilities }\end{array}$ & $\begin{array}{l}\text { Post-hierarchical structure based on } \\
\text { topological and hyper-real spaces and virtual } \\
\text { places }\end{array}$ \\
\hline Retail offer & $\begin{array}{l}\text { Goods and services according to standardized } \\
\text { mass production lines }\end{array}$ & $\begin{array}{l}\text { Goods and services according to a wide } \\
\text { variety of lines and market segments }\end{array}$ & $\begin{array}{l}\text { Brands, signs, atmospheres and consumer } \\
\text { experiences }\end{array}$ \\
\hline Functions & $\begin{array}{l}\text { Shopping places as utilitarian premises. } \\
\text { Economy of needs }\end{array}$ & $\begin{array}{l}\text { Stores as spaces of synthesis: retailtainment. } \\
\text { Economy of signs }\end{array}$ & $\begin{array}{l}\text { Stores as places of entertainment and life } \\
\text { experiences. Economy of fascination }\end{array}$ \\
\hline
\end{tabular}

Source: Adapted from Cachinho and Barata-Salgueiro (in press).

ued by the consumer-society culture, the second is growing fast and everyday conquers additional territories.

The city which emerges from the new retail spaces dedicated to exploring their symbolism through communication, has very little in common with the city that may be directly perceived by the senses, and that has been described by geographers in their writings and thematic maps working according to different perspectives and more or less complex models. When we come down to it, we realize that this sort of city is hyper-real because almost all is simulated; the closest version we can get to this kind of city is the one we see at the theatre or the cinema (Amendola, 2000). And similar to what is found at the theatre, the (consumer) show is paramount, using the same props to produce the staging of the performance.

Because they are deeply entrenched in the primacy of "indirect commodification " (Crawford, 1992) and "adjacent attraction" ${ }^{2}$ " (Sennett, 1977) in the symbolism of their architecture and design and in the sign-value of the merchandise, the new retail spaces cast the city into a show where the consumers are both the spectators and the actors. In this kind of city, material reality in the retail spaces only works as a pre-condition of its own existence. The spaces are necessary because they act as a stage, as the props and the scripts for representations that feed consumer experiences. However, they are not enough in themselves owing to the fact that it is on the symbolic level and in the dialogue happening with the consumer that the show, its representations and its narratives are carried out. In order to bring this about, the city becomes real, or rather; it begins to become a part of each person's imaginary. So, in the way that people may experience and appreciate it, it is necessary that they become consumactors ${ }^{3}$ to be able to travel beyond the landscaped patchwork that they are looking at. They need to immerse themselves in a world of fantasy, dreams and illusion emanating from the hidden agenda of the merchandise, the theatricality of recreational environments and the sensations awakened by lived experiences (Cachinho, 2006). In the postmodern metropolis of new retail spaces and consumer places, deliberately planned to seduce, intercept and create consumactor expectations, the border between the stage and stalls disappears and all the spaces tend to become "places of liminality" (Goss, 1993). The individuals making

\footnotetext{
1 A process by which nonsalable objects, activities and images are purposely placed in the commodified world of the mall (Crawford, 1992, p. 14).

2 The basic marketing principle by which the most dissimilar objects lend each other mutual support when they are placed next to each other. Sennett (1977) explains this effect as a temporary suspension of the use value of the object, its decontextualised state making it unexpected and therefore stimulating (Crawford, 1992, pp. 14-15).

3 The expression consumactor designates the kind of consumer who normally goes to shopping malls as if s/he is on the stage playing with consumption; this is an activity through which the tendency is to permanently rebuild one's identity (Cachinho, 2006). Some authors, like Bäckström (2006), classify this kind of consumer as a recreational shopper.
}

use of them wind their ways from one representation to another without ever really getting to know where fiction ends and reality starts. But it does not really matter. In a purely simulated, disguised setting, where social representation does not imitate the real thing but rather the imagined thing, the world necessarily has to be real because this is the one that is sought after, not the imaginary one (Amendola, 2000).

In short, from the viewpoint of the physical and material environment of retail spaces, or the retailscapes, the city might even be shaped by distances; it might even be made of centralities and peripheries, of localities provided with better or weaker accessibility, organizing itself according to hierarchical principles and for investors to manage things in accordance with ideas based on the economic rationale. Nevertheless, from the viewpoint of the consumers, retail landscapes go far beyond their material and spatial confines, and only from a reductionist stance can these factors be likened to a simple stage. The power of the symbolic dimension of the built environment, exploited by architects, designers and marketers, leads to the emergence of another city, rooted in the landscape of symbols and signs, invisible to the unsuspecting but no less felt for all those elements. Actually, its existence and form is limited only to the imaginative and representational capacity of the consumactors.

\section{Shopping places as fields of resources for consumer projects}

The changes in the organization and functioning of the urban retail systems presented earlier on, reveal that shopping strategies have clearly taken a new direction, swerving away from the producers heading to the consumers. With the development of the consumer society and the dissemination of its values, the most dynamic retailers have realized that the key to their success lies in the consumers. They have therefore decided to stop merely being the producers' intermediaries to become the consumers' spokespeople, matching their shops' offers and atmosphere to the needs and desires of their customers (Cachinho, 2002; Hetzel, 2002; Mermet, 1996; Mermet, 1997). As the consumers draw closer, retailers have truly re-position themselves in the market. Besides carving out a new identity for themselves that is more in keeping with the role they play in society (Dupuis, 1988), they re-shape the retail-supply relations, including the manufacturers' production strategies (Foord, Bowlby, \& Tillsley, 1996; Wrigley \& Lowe, 2002). This is contrived through an interplay of personalization and emotions which strengthen the attractiveness of the shops, thereby transforming them into places of life experiences (Lipovetsky, 2006; Miles, 2010; Wrigley \& Lowe, 2002). By doing so, they raise the consumers' levels of satisfaction which has been defined by Giese and Cote (2002). These authors have drawn up a summary of emotional responses of varying intensity in relation to product acquisition and shopping experiences. 
At the centre of the retailers' change in attitude is the idea that has been diffused by thinkers such as Baudrillard (1975), Featherstone (1991), Firat and Venkatesh (1993), Firat and Dholakia (1998) or Lipovetsky (2006), where in a postmodern urban society consumption has basically changed into a social act where symbolic meanings, codes and social relations are (re)produced. Through consumption and the places stimulating it, people tend to not only satisfy their needs and wishes but also make sense of define themselves, create their statuses and positions in society and forge images of themselves that they wish to transmit to others. Within this setting, even in the most fragmented ways, identity tends to be more and more sought after and recognized by others, not on the basis of what a person does/produces, but rather through a constellation of goods, services, ideas and experiences which they consume as well as the places they live in and the spaces they go to and use in the practice of everyday life (Firat \& Dholakia, 1998; Goss, 1995; Morace, 2009).

This way of looking at consumption and consumers has meant a radical change as much where understanding how the valuecreation of the commodities has been generated as the role played by the retailers in the production-distribution-consumption chain. With regard to the production of value, the question is simple. If we accept the ideas of Marx (1973), that the act of production is at every moment also an act of consumption and vice versa, or the idea of Baudrillard (1970) that consumption has become an activity of the production of meanings and a field of symbolic exchanges, consumers do not consume the products, but rather, the meaning of these products and the image they convey, we cannot continue to conceive consumption as unproductive or the last moment of the chain when the value created by production is destroyed or devoured by consumers (Williams, 1997).

As far as understanding the role played by the retailer in valuecreation, the changes are no less important. At least when considering the most pro-active retailers, the tendency is from being the producers' mere intermediary where they occupy an intermediate position in the traditional chain connecting production to consumption, to now being seen as representing a number of productive agents in the production cycle which is always composed of the stages of manufacturing, distribution and the consumption of the commodities, as well as the symbols and signs in real or virtual places and environments.

The strategic orientation of shops so that they offer life experiences and their appropriation in the individuals-consumers' acceptance of such, has been explored by marketing in many different contexts, mainly going through the lens of consumer culture theory (Arnould \& Thompson, 2005) and the resource-based theory (Vargo \& Lusch, 2004) to do so. According to these perspectives, consumption and consumer choices are above all socio-anthropological phenomena. In this sense, research undertaken in this field has sought to explore the way in which consumers manipulate and transform symbolic meanings encoded in the offer (goods, services, brands, ...) and shopping venues in order to build their life projects, both individual and collective (Debenedetti, Mencarelli, \& Debenedetti, 2011; Holt, 2002). Making use of Arnould's (2005) terms, in market-driven societies, consumption becomes a means of producing one's self, one's self image in the community and one's tribal membership. Thus, people engage in shopping to accomplish a variety of projects for which they mobilize their own economic, social, and ideological resources. In turn, retail firms compete for a role in the culturally constituted projects that consumers pursue by offering a mix of resources, which can be used by consumers. Arnould (2007) reports the deployment of these resources through the notion of consumer agency that reflects the way consumers, who base themselves on their own cultural resources, accept, reject and/or convert the resources supplied by retailers.
In order to grasp the full potential of CCT when understanding the dynamics of retailing, Arnould (2005), following Vargo and Lusch (2004), makes a clear distinction between two kinds of cultural resources: the operant resources, generally intangibles, related to skills, knowledge, competences, values and ideologies, and the operand resources, usually tangibles, on which the action of the operant resources produces effects. Breaking with the view of classical marketing models, where consumers are seen, at best, as valuable co-producers or operant resources in the production function of firms, Arnould (2005) states that retailers would be better conceptualized as operant and operand resource suppliers that compete for shares of consumer operant resources. From this point of view, firms become merely resource suppliers. Perceived value creation takes place when people, playing the role of consumers, engage in the exploitation of resources to fulfill their needs and to organize their personal and social life projects (Arnould, 2007; Debenedetti et al., 2011).

In the research applied to retail, Arnould (2005, pp. 91-93) identifies four main categories of cultural resources: economic, utopian, ludic, and temporal. However, other types of resources can be found, depending on the features of the market and the socio-cultural environment. In short, retailers and shopping places: (i) offer economic cultural resources when they help consumers' pursuit of identity projects organized around values oriented to frugality, thriftiness, and value for money or conversely luxury; (ii) symbolize utopian cultural resources when they facilitate consumers' pursuit of a utopian world or selves; (iii) work as ludic resources when they facilitate consumers' pursuit of play, including activities, such as, transcendental experiences, fan behaviors, imaginative role-playing; and finally (iv) operate as temporal resources when they enable the enactment of consumers' preferred time-styles.

As a field of cultural resources, retailers and shops play a crucial role in the life of individuals-consumers because in a society geared to consumption, they allow them to fulfill a good part of their life projects. Nevertheless, because commodities and shops are inanimate, in themselves they do not have the power to carry out such noble functions. In order to make this possible and to become alive or gain meaning, they need to be activated by the individuals-consumers who draw upon their own resources for the effect (Arnould, 2005). In other words, although the retailers provide the offer and the consumer atmospheres, it is only at the symbolic level and in the dialogue that ensues with the consumers that the commodities and the shops become meaningful. The experiences which are forged and gain meaning are then absorbed into the consumers' life projects.

The idea that commodities and consumer spaces may be envisaged as a source of resources that the consumers are able to call upon so as to follow up their personal and collective projects, has been substantiated by various studies undertaken in different geographical settings. As an illustration, in the field of shopping mall patronage, Varman and Belk (2011) have recently shown in their post-colonial analysis of shopping malls as hybrid sites, how young consumers in India, looking upon these spaces as Western spectacles, deploy them to transform their Third World identities. In making an in-depth examination of young American girls' mall experiences, Haytko and Baker (2004) have demonstrated how the girls plan their trips and use the shopping mall to pursue their conventional social projects. Finally, the research conducted by Erkip (2003) in Ankara reveals how the development of shopping malls is shaping the identity of urban Turkish citizens who are searching for modernity through these new retail and consumption venues. Due to the cultural features of Turkish society, shopping malls do not give the same opportunities to all the consumers. Erkip's research clearly shows that they exclude the poor and specially benefit working women. As they seem to be 
more public and democratic than the streets, shopping malls are generating an increasing process of the feminization of the Turkish flâneur.

Studies that have explored the cultural dimension of shopping places are far from being restricted to shopping malls. Smith, Gourgott, and Devine (2001) explain the success of many health clubs and gyms as third places (Oldenburg, 2001), above all in their capability to create a friendly inviting atmosphere which facilitates making social relationships among gym-goers. In the opinion of gym-goers in the Californian gym study, social conviviality is the most important aspect of their gym experience. The possibility of sharing the same place with a group of people where they feel comfortable, safe, and welcome, not only gives gym-goers the motivation and perseverance to invest in physical exercise but also foster their self-esteem and well-being. By becoming involved in this friendly atmosphere, people feel as if they are truly accepted, appreciated for their good qualities and generally valued as individuals; such situations therefore form the ingredients that fully nourish the self and help in personal and collective identity formation. Kozinets et al. (2002) explored the themed flagship brandstores in terms of the mythological appeal of the narratives suggested by their physical and symbolic environment. Their research examined Chicago's ESPN Zone ${ }^{4}$ by carrying out a set of interviews with managers, workers and several dozen customers, as well as by observing and participating in store activities. They concluded that consumers interacted and "read" the megastore physical environment for the story it told them. Consumer perceptions of their own experiences revealed that the ESPN Zone environment provided a cultural connection to ideas of growth and development, such as those based on travel, education, self-improvement, training and development, and spirituality. The power of themed brandstores in the consumers' experiences is also explored by Borghini et al. (2009) using the example of the American Girl Place. Through their ethnographic study, supported in participantobservation of and on-site interviews with consumers, these authors show how retailing in this brand-environment is an ideological affair. The brand ideology is overwhelmingly present in the different themed focal areas structuring the American Girl Place: the Museum, Theatre, Salon, Library, Café, and the Photo Studio. Extending Arnould's (2005) idea of resource exchange, Borghini et al. (2009, p. 372) show through this investigation "that not only must retailers provide resources in a general way that are used by consumer's as part of their life projects, but that the retail experience itself can become an anchor for the ideological brand, an important marker that a potent and emotionally rich set of social values is up for grabs".

The cultural dimension of retail and consumption also shapes the most banal shopping venues focused on the provision of loworder goods and services. Woodruffe-Burton and Wakenshaw (2011) carried out an investigation into the symbolic and experiential values of grocery shopping and consumer experiences, applying an existential phenomenological interview to ten women living in the UK. They reveal how consumers express and construct their selves and identities through their food shopping and consumer practices by appropriating the cultural and social meanings contained in the set of resources provided by retailers.

The cultural approach of retailing was also tested in two medium-size Portuguese cities (Cachinho, 2002 and Barata-Salgueiro, Cachinho, \& Rocha, 2007). Consumers were asked what meanings they gave to the shops they patronized. A large number of consumers tended to describe the shops by referring to a set of attributes that clearly transcended the material dimension, carrying them into the world of the intangible, of signs and meanings which nur-

\footnotetext{
${ }^{4}$ Chicago's ESPN Zone later closed down in June 2010 for lack of customers and ESPN Zone only operates in California now: Cf. http://abclocal.go.com/wls/story?section=news/local\&id=7499787 (accessed 23.12.11).
}

ture consumer experiences. Similar to what has been observed in the case of the commodities, many stores have also become a source of pleasure, fun, exoticism, prestige, nostalgia, friendliness, tradition, identity, personal development, sociability, responsibility, ethnicity, etc. For many consumers, these attributes are more than the goods and services sold by such shops, and they influence their decision to patronize certain retail spaces rather than others.

Of course, not all consumers give the same values to the same shops and not all the shops working in the same branch of retailing communicate the same values. For example, as regards McDonald's restaurants, while some consumers who are in a hurry value the fast service, the younger customers usually go to these venues to hang out because of their convivial atmosphere, their party-spirit and liveliness. While some consumers think the quality/price relationship and getting the best out of it are important, others esteem McDonald's for its laxity where they can break the rules, as for instance, eating with their fingers and pushing aside good table manners. In any event, these features have already been exploited by the company itself in its advertising strategies.

\section{Consumerscapes: why they matter to the resilience assessment of urban retailing}

Several studies have shown the great potential exerted by shopping and consumption in regenerating urban areas mainly in city centers and docklands which have started on a downward spiral. Investigations carried out in different urban contexts, namely by Robertson (1997), Mitchell and Kirkup (2003), Dixon (2005), Jayne (2006), Claxton and Siora (2008), Padilla and Eastlick (2009), Littlefield (2009) and Tallon (2010), illustrate this urban revitalization capital quite well. Yet, paradoxically, urban retail systems have never been so vulnerable and today their sustainability has been seriously threatened. The suburban retail revolution triggered by the new retail formats, coupled with the spread of large retail chains and the retraction of small shopkeepers, have deeply affected the balance of retail systems in many cities, preventing them from responding to the needs, wants and desires of the different groups of consumers. These imbalances influence the "disadvantaged consumers" above all (Bromley \& Thomas, 1993; Westlake, 1993, 1995; Williams \& Hubbard, 2001), such as the disabled, the elderly, car-less households, and low income groups who are constrained to use the local and neighborhood facilities.

Matters to do with the "health" of urban retail systems, as well as types of remedial or preventive measures have been explored by several authors over the past decades. Berry (1963), Meir and Marcus (1983), Borchert (1988), Zentes and Schwarz-Zanetti (1988), Ravenscroft (2000), Thomas and Bromley (2003), Balsas, Kotval, and Mullin (2004), ODPM (2005, 2009), Guy (2007), and Wrigley and Dolega (2011) are just same examples of different approaches that have been conducted on the subject. Berry (1963) was the pioneer in this field when he drew up a model of development of the intra-urban retail systems and made a typology of the factors underpinning their loss of vitality and economic feasibility, thus dragging them down into their decline and possible death. Berry stated that all urban retail systems comprise a set of shopping districts endowed with a life cycle. Physical, economic, functional (technological), and frictional factors explain not only the genesis and development of different types of shopping centers, but also their decline and blight over time.

Another area of research work carried out in the last few decades is illustrated in the work done by Ravenscroft (2000) and the ODPM $(2005,2009)$. In following years of decentralization and the suburbanization of retailing and services, attention is now focused on assessing the health of town centers. Besides designing the conceptual framework and the methodology suited 
to making a micro-scale analysis, these studies also seek to develop a set of key indicators able to monitor and evaluate the vitality and viability of town centers. The option to recentralize and commitment to the concept of the compact city largely explain the wide acceptance of these studies in planning and management of town centers. In the UK, its application to urban planning culminated in the successive versions of Planning Policy Statements, especially in versions 6 and 4 (ODPM, 2005, 2009), that included the definition of the Town Centre Health Check Indicators, to be used in the assessment of the vitality and viability of shopping centers.

Finally, the last research group is linked to the evaluation of the performances and frailties of urban retail systems and the factors underlying the behaviors recorded using the lens of resilience. The work carried out by Wood, Lowe, and Wrigley (2006), Wrigley and Dolega (2011) and Cachinho and Barata-Salgueiro (in press), exemplify this new approach. Wrigley and Dolega (2011) design their study based on a sample of 267 town centers and high streets spread across four regions of the UK. Retail changes in these shopping centers are evaluated in terms of the losses and gains of different types of retail and services provision following the macroeconomic shock waves of the global crisis. Drawing on the concept of adaptive resilience identified by Martin (2011), which stresses "the anticipatory or reactive capacity of systems to minimize the impacts of a destabilizing shock" (Wrigley \& Dolega, 2011, p. 2346), retail and service unit closures, empty units and increases in "vacancy rates" of shopping centers are interpreted as a product of a dynamic and evolutionary process experienced by town centers and high-streets during the economic crisis. Thus, differences in performance exhibited by UK town centers and high streets are related to their resilience capacity to withstand the impacts of economic crisis. Likewise, gains and losses exhibited by different types of retail and services, namely by "comparison" and convenience retail and services categories are understood as a sign of the system's adjustment in order to respond to shifting consumer tastes and fluctuating levels of market demand. Some of these changes are even regarded as essential to the health of town centers and high streets.

The research conducted by Cachinho and Barata-Salgueiro (in press) falls within the same line of thought. The resilience of retail urban systems is defined as the ability of stores and shopping areas to tolerate and adapt to changing environments that challenge the retail system's equilibrium, without causing it to fail to perform its functions in a sustainable way. The term equilibrium is used here to describe the stage of the retail system where the network of shopping districts and the mix of retail and service facilities are endowed with the properties that ensure its vitality and economic viability, as well as the efficient response to the needs of all types of consumers, including the most disadvantaged in terms of mobility, who are more dependent on the convenience and local stores. The resilience of shopping spaces and environments is assessed by reading retailscapes through the lens of economic and cultural approaches.

One way to appraise the cultural value of stores as well as the frailties and the resilience of shopping districts is to study consumerscapes. Indeed, if most of the changes affecting the retail systems are able to explain themselves through shifting life-styles and consumer practices or, if you like, through the way the consumers read the retailscapes as being the fountainheads of resources and chose or reject them according to their life projects, it is hardly likely that the performances of shops and shopping areas will not reflect the consumer images and levels of satisfaction that we seek to portray in the expression consumerscapes.

Several factors justify the role that consumerscapes are able to play in the evaluation of the weaknesses and the resilience of shopping places. Firstly, it is important to stress that they may form a valuable source of information about the way consumers read and interpret them and call upon shopping landscapes so as to build up their shopping experiences which feed their life projects. Thus, when studying them, it is possible to understand whether the available shopping areas in terms of retail mix, assortment and resources respond to consumer needs. The data is of interest to both retailers who may direct their management strategies according to the problems that have been pinpointed, and to the public authorities implicated in policy-making, and the measures and actions that help to attenuate weaknesses in the retail systems, mainly where less competitive retailers and more underprivileged consumers are concerned. Secondly, the consumerscapes are also an important indicator of the consumers' satisfaction in terms of shopping places and retail facilities. Although the meaning of the expression "consumer satisfaction" is far from reaching consensus in academia because multiple variables are involved in its configuration, Giese and Cote (2002) have proposed a definitional framework comprising three basic components: (i) a summary affective response of varying intensity; (ii) with a time-specific point of determination and limited duration; and (iii) directed towards focal aspects of goods acquisition and/or consumption. Viewed in this light, this concept can be empirically assessed by developing context-specific measures of satisfaction that are consistent with the research goals.

The importance of knowing the levels of consumer satisfaction lies in the fact that several empirical investigations have shown that there are important linkages among the attributes of consumers' perceptions, their overall satisfaction and the stores' sales performances. Changes in customers' satisfaction result in changes in stores' sales performance (Gómez, McLaughlin, \& Wittink, 2004). In this context, in the same way that shopkeepers have ample reasons to establish consumer satisfaction programs in order to attract loyal customers and maximize profits, the public authorities concerned with the health of shopping districts should also use this conceptual category to conceive planning policies best suited to problem-solving whether they have to do with the retailers or the consumers. In raising consumer satisfaction levels whereby the offer and the attributes of the public space meet their needs, the retailers and public authorities would surely help to curtail the frailties witnessed in shopping districts and in doing so, improve the system's overall resilience.

\section{The consumerscapes of three neighborhood shopping districts in Greater Lisbon}

In order to appropriate the consumerscapes and evaluate the levels of consumer satisfaction with the shopping districts and retail facilities they patronize through their shopping practices, a survey was carried out in three middle-class neighborhoods in Greater Lisbon: Campo de Ourique, home to 25,000 inhabitants, Telheiras with around 28,000 residents and Colinas do Cruzeiro, planned for 12,000 inhabitants, although since this quarter is quite recent, many apartments in it are still left for sale. Fig. 1 provides the location of these neighborhoods in relation to Downtown, the main shopping district of Greater Lisbon.

The empirical research involved a questionnaire to a sample of 375 consumers (125 in each district), stratified according to age and gender; a careful field observation of the built environment and its appropriation by the resident population (conducted at different times of the day on different days of the week), as well as a set of 30 in-depth interviews to consumers residing in the three neighborhoods. The data collected from these in-depth interviews played a twofold role. Apart from complementing the information given in the questionnaire, they also illustrated the relationship between the consumers' life projects and the cultural resources made available by the shopping districts. 


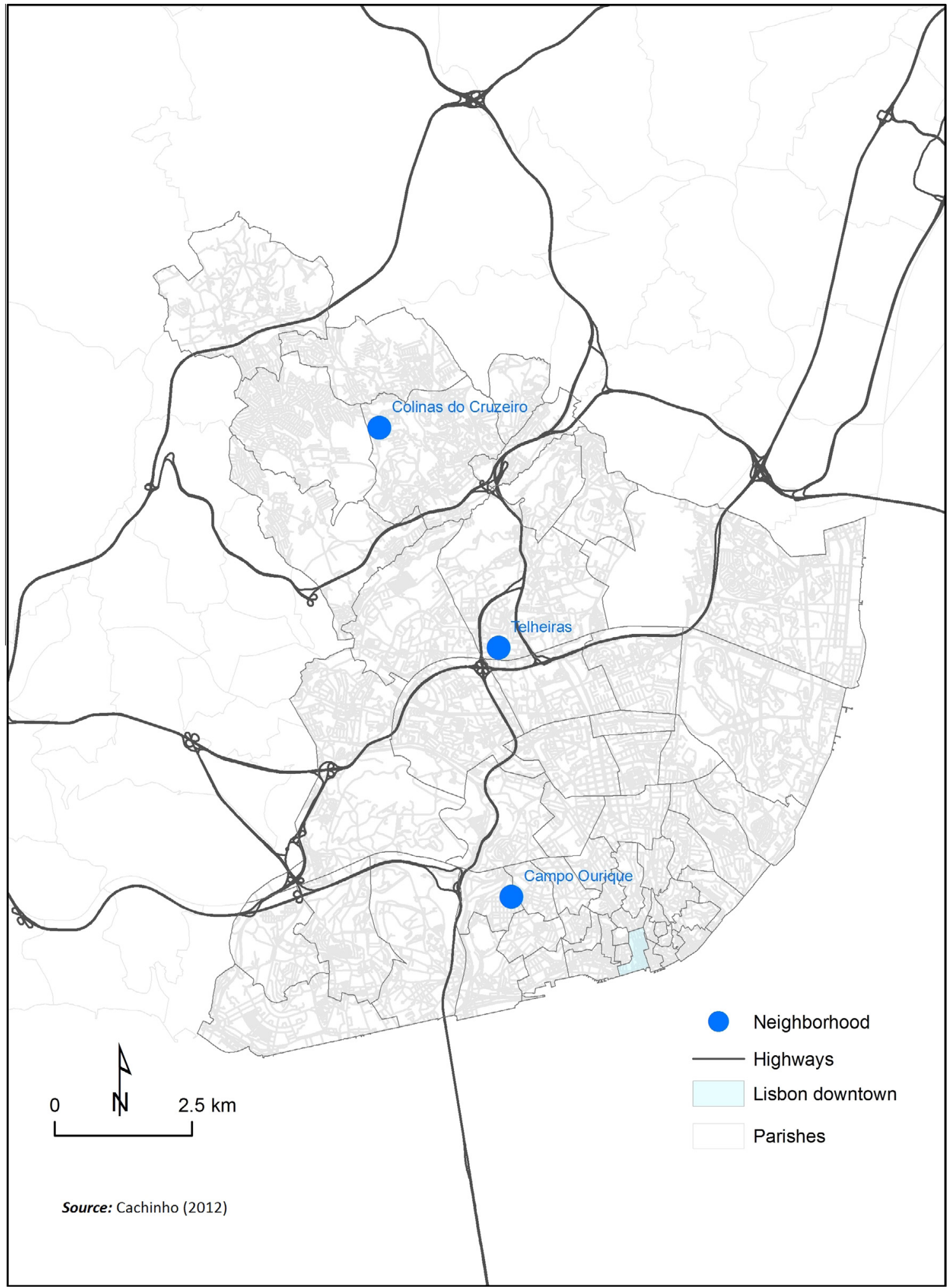

Fig. 1. Location of shopping districts in relation to the city center.

The survey contained three types of questions: (i) questions related to the targeted population's profile that could explain the differences in the images that were found. This group included variables such as age, gender, qualifications, household size, occupational status, place of residence or loyalty in terms of the convenience and local shopping facilities; (ii) questions regarding the different dimensions of the neighborhood's representations, meaning the characteristics of the physical environment, the shopping supply, the public space, perceptions of safety and accessibility or driving and parking conditions; and (iii) questions connected to the levels of consumer satisfaction as regards the retail/service facilities in terms of the quality of the assortment, the variety of 
the tenant mix and the neighborhood's weaknesses (aspects in the district that people liked and disliked). The survey's structuring variables were chosen in conformity with the Project's aims; its references were based on CCT (Arnould, 2005) where the focus was placed on the regeneration of neighborhood retail (Beyard, Pawlukiewicz, \& Bond, 2003) and the development of highly successful shopping districts, particularly in town centers and main streets (Bohl, 2002).

Although mainly middle-class or upper-middle class inhabitants live in the three neighborhoods and the available retail offer has to compete with other retail spaces, like shopping malls, hypermarkets and discount stores that have been built in close vicinity, the location of these neighborhoods in the city, their urban attributes and the position they occupy in the "life cycle", apportions each one with its own important features. Campo de Ourique (Fig. 2) is a historical district with a strong identity, situated in the hyper-centre of the city. It is inhabited by an aging population, and endowed with a rich retail mix offering convenience and comparison goods and services, but perceived as a decaying shopping neighborhood. At the opposite end of the scale, Telheiras (Fig. 3) is basically a fairly recent, well-preserved residential neighborhood with a few commercial streets, situated in the periphery of the city. It is inhabited by young, educated people ( $40 \%$ are under 25 years old and $60 \%$ have a higher education degree). From the point of view of retailing and services, the area is undergoing a clear process of consolidation as a neighborhood shopping district. Finally, Colinas do Cruzeiro (Fig. 4) is quite a recent high-density neighborhood situated on the outskirts of the city. People living in this neighborhood largely conform to two kinds of young households, both in the first stages of the family life cycle: the DINKy (Double Income no Kids yet) and DIWK (Double Income with Kids). Although the provision of housing is the most important activity in the district, most buildings were planned to receive a variety of retail and service uses, specially aimed at the local market.

Table 2 presents the business structure of the three shopping districts, measured in the number of outlets according to whether they are retail and service categories. Significant differences mark the business mix of the three districts, particularly in relation to the share of units geared to convenience and comparison retail and service items. These differences, combined with the resident population's profile, the position of each neighborhood in the "life cycle" and other physical and social amenities, help to explain the images and the levels of satisfaction expressed by people answering the survey. We shall now briefly present and discuss the findings.

There are three questions included in the set of considerations raised by the consumer survey that deserve particular attention when assessing the weaknesses and levels of resilience of the urban commercial systems. The first issue has to do with the representations as regards the attributes that consumers tend to favor in their shopping experiences. Fig. 5 shows the degree to which consumers most fully agree with the statements made in the survey that describe the shopping area's characteristics. We are able to see that each of the three neighborhoods has a different profile. Indeed, in accordance with the representations of most of the people taking part in the survey, Campo de Ourique, Telheiras and Colinas do Cruzeiro only share the same opinion in terms of the pleasantness of the built environment.

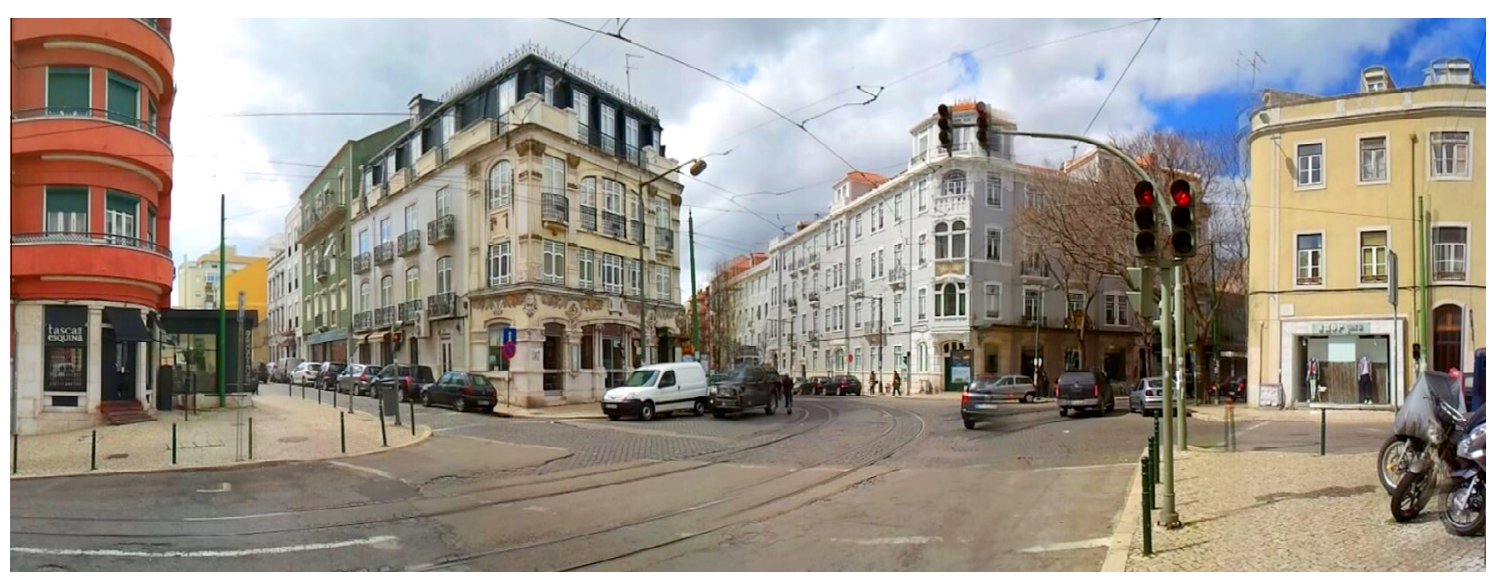

Fig. 2. Panoramic view of the entrance to the neighborhood of Campo de Ourique. Source: Cachinho (2012).

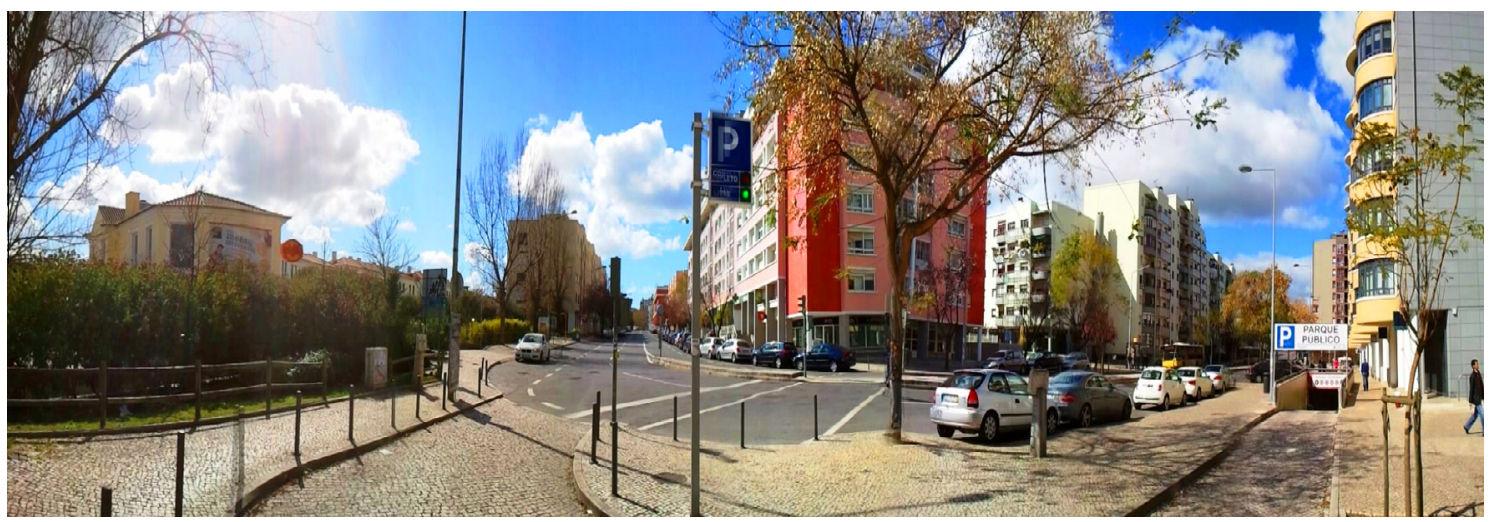

Fig. 3. Panoramic view of the entrance to the neighborhood of Telheiras. Source: Cachinho (2012). 


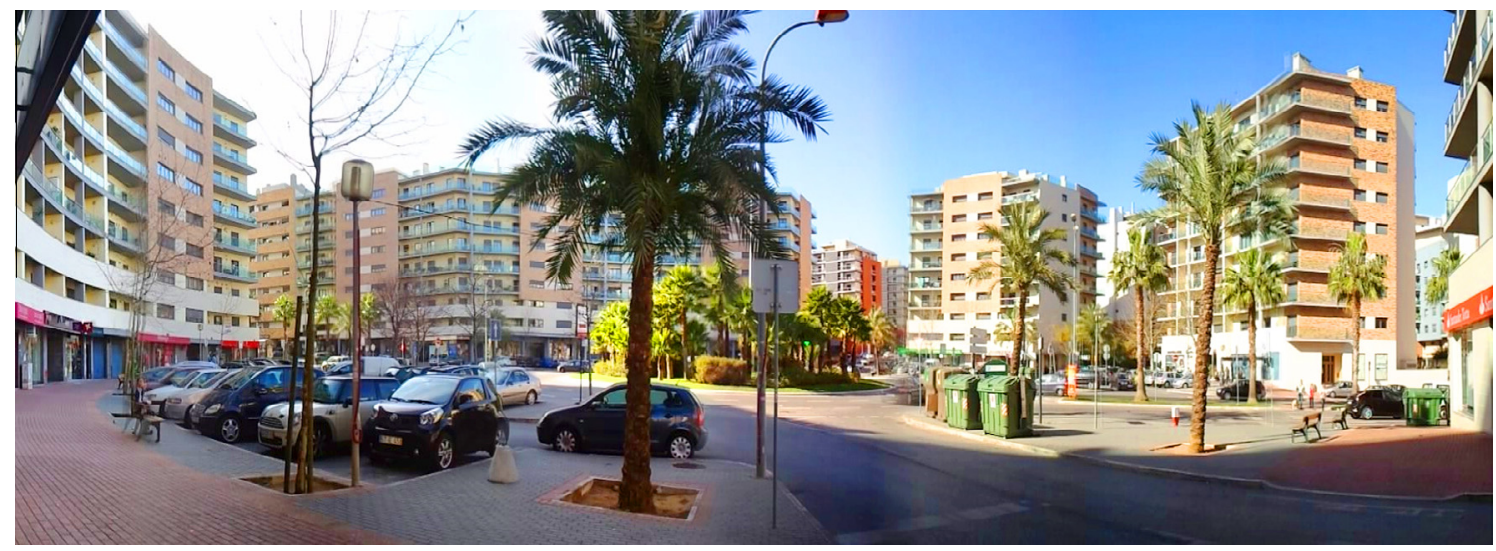

Fig. 4. Panoramic view of Odivelas square in the neighborhood of Colinas do Cruzeiro. Source: Cachinho (2012).

Table 2

Retail and service mix of shopping districts.

\begin{tabular}{|c|c|c|c|c|c|c|}
\hline \multirow[t]{3}{*}{ Retail and service mix } & \multicolumn{6}{|c|}{ Shopping districts } \\
\hline & \multicolumn{2}{|c|}{ Campo Ourique } & \multicolumn{2}{|l|}{ Telheiras } & \multicolumn{2}{|c|}{ Colinas Cruzeiro } \\
\hline & $N$. stores & $\%$ & $N$. stores & $\%$ & $N$. stores & $\%$ \\
\hline Food and drink & 37 & 7.2 & 18 & 4.5 & 15 & 7.2 \\
\hline Clothing, textiles and footwear & 87 & 16.9 & 28 & 7.0 & 13 & 6.3 \\
\hline Furniture and household goods & 70 & 13.6 & 25 & 6.3 & 14 & 6.8 \\
\hline Health and beauty & 23 & 4.5 & 23 & 5.8 & 7 & 3.4 \\
\hline Culture and Leisure & 25 & 4.9 & 22 & 5.5 & 4 & 1.9 \\
\hline DIY, hardware and related goods & 3 & 0.6 & 10 & 2.5 & 2 & 1.0 \\
\hline Professional equipment & 1 & 0.2 & 12 & 3.0 & 5 & 2.4 \\
\hline Cars and motorcycles & 10 & 1.9 & 9 & 2.3 & 13 & 6.3 \\
\hline Other non-food retail & 13 & 2.5 & 1 & 0.3 & 2 & 1.0 \\
\hline Repair services & 30 & 5.8 & 1 & 0.3 & 1 & 0.5 \\
\hline Personal services & 38 & 7.4 & 56 & 14.0 & 18 & 8.7 \\
\hline Culture and Leisure services & 15 & 2.9 & 25 & 6.3 & 2 & 1.0 \\
\hline Health and care services & 22 & 4.3 & 17 & 4.3 & 16 & 7.7 \\
\hline Bank and insurance services & 31 & 6.0 & 55 & 13.8 & 41 & 19.8 \\
\hline Services to the community & 7 & 1.4 & 1 & 0.3 & 15 & 7.2 \\
\hline Restaurant and cafés & 90 & 17.5 & 85 & 21.3 & 34 & 16.4 \\
\hline \multirow[t]{2}{*}{ Other services } & 12 & 2.3 & 11 & 2.8 & 5 & 2.4 \\
\hline & 514 & 100.0 & 399 & 100.0 & 207 & 100.0 \\
\hline
\end{tabular}

Source: Author, fieldwork conducted in April and May 2011.

The Campo de Ourique neighborhood registers the best performances in most of the attributes. The variation and quality of the merchandise makes this quarter an interesting one in which to shop because consumers are able to find almost everything they need in it. This factor, together with the environmental amenities offered in its public spaces are responsible for an appreciable number of respondents viewing the place as good for strolling in, window-shopping and meeting people, as well as an interesting place to have lunch or dinner with family and friends. The most unfavorable opinions are about parking, car circulation, accessibility, the cleanliness of the public space and safety. However, with scores situated between $3 \%$ and $12 \%$, it means that only a small number of respondents did not acknowledge these attributes.

The representations which respondents from Telheiras have about their neighborhood clearly situate the attributes between those for Campo de Ourique and those for Colinas do Cruzeiro. The best performances are about the environmental amenities and accessibility. Nevertheless, a significant number of people also appreciate the quality and assortment of merchandise on offer even if it is obviously destined to supply the local population. Friendly shopkeepers, the fact that the public space is interesting and is good for strolling in with the family are other factors that tend to stamp the neighborhood's identity. In contrast, the most unfavorable images are connected with parking difficulties, circulation and safety on the one hand, and on the other, with the characteristics of the retail offer. Apart from the fact that people acknowledged its quality, it is manifestly insufficient to give the neighborhood its own commercial identity or even make it an interesting place for shopping.

Lastly, although the images of the Colinas do Cruzeiro reveal some specific features, by and large, they tend to resemble most of the attributes observed for Telheiras. The best performances are found to be in the amenities of the built environment, accessibility and the feeling of safety. The most unfavorable aspects single out parking and circulation on the one hand, and on the other, the poor assortment of offer that only seem to fully satisfy $8 \%$ of the respondent population. The deficit in this sphere is explained by the fact that the quarter is perceived by most of the respondents as being a fairly uninteresting place in which to shop and most of them go to other shopping districts, mainly to the enclosed shopping centers on the outskirts of the neighborhood. 


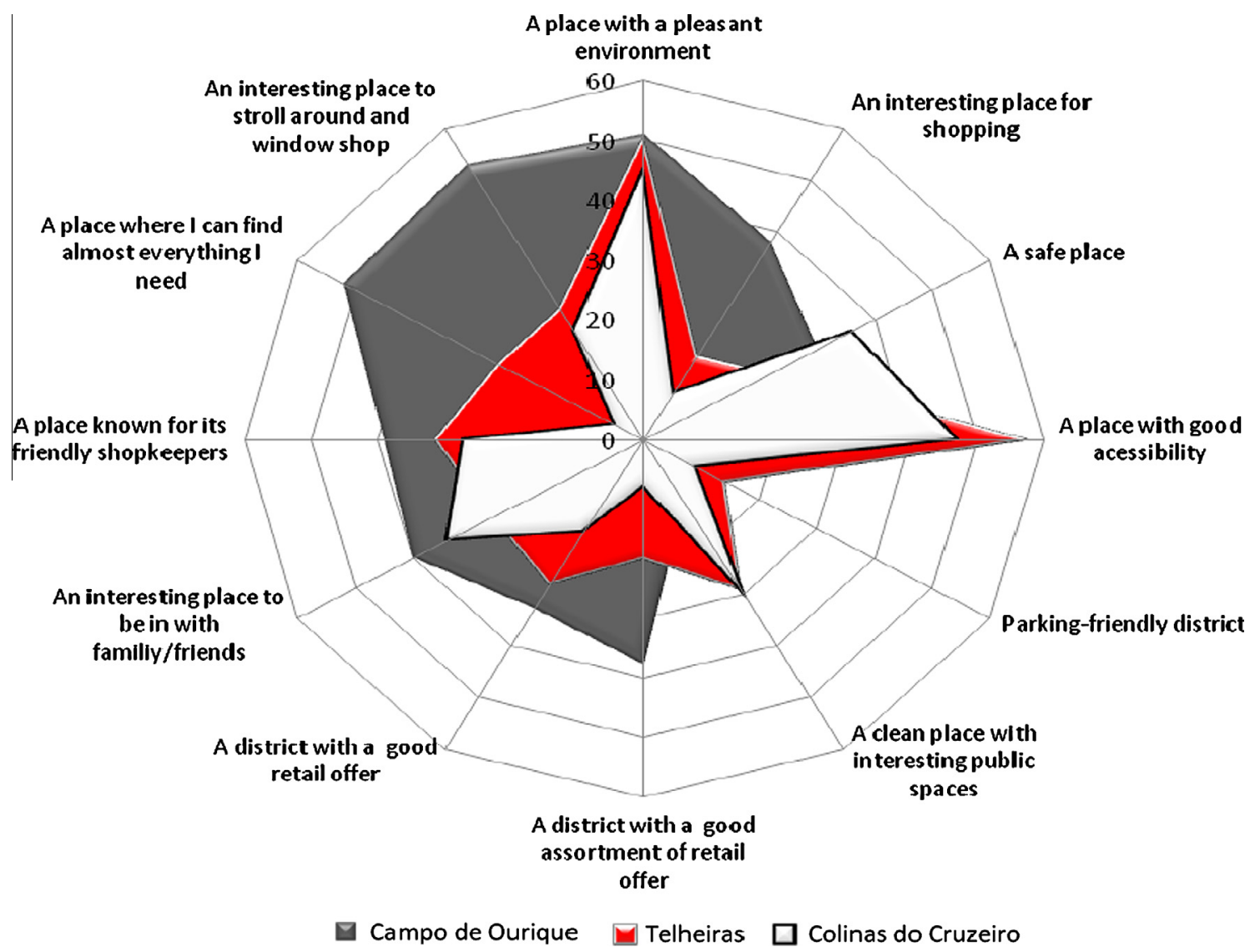

Fig. 5. Consumers' perceptions of neighborhoods. Source: Cachinho (2012).

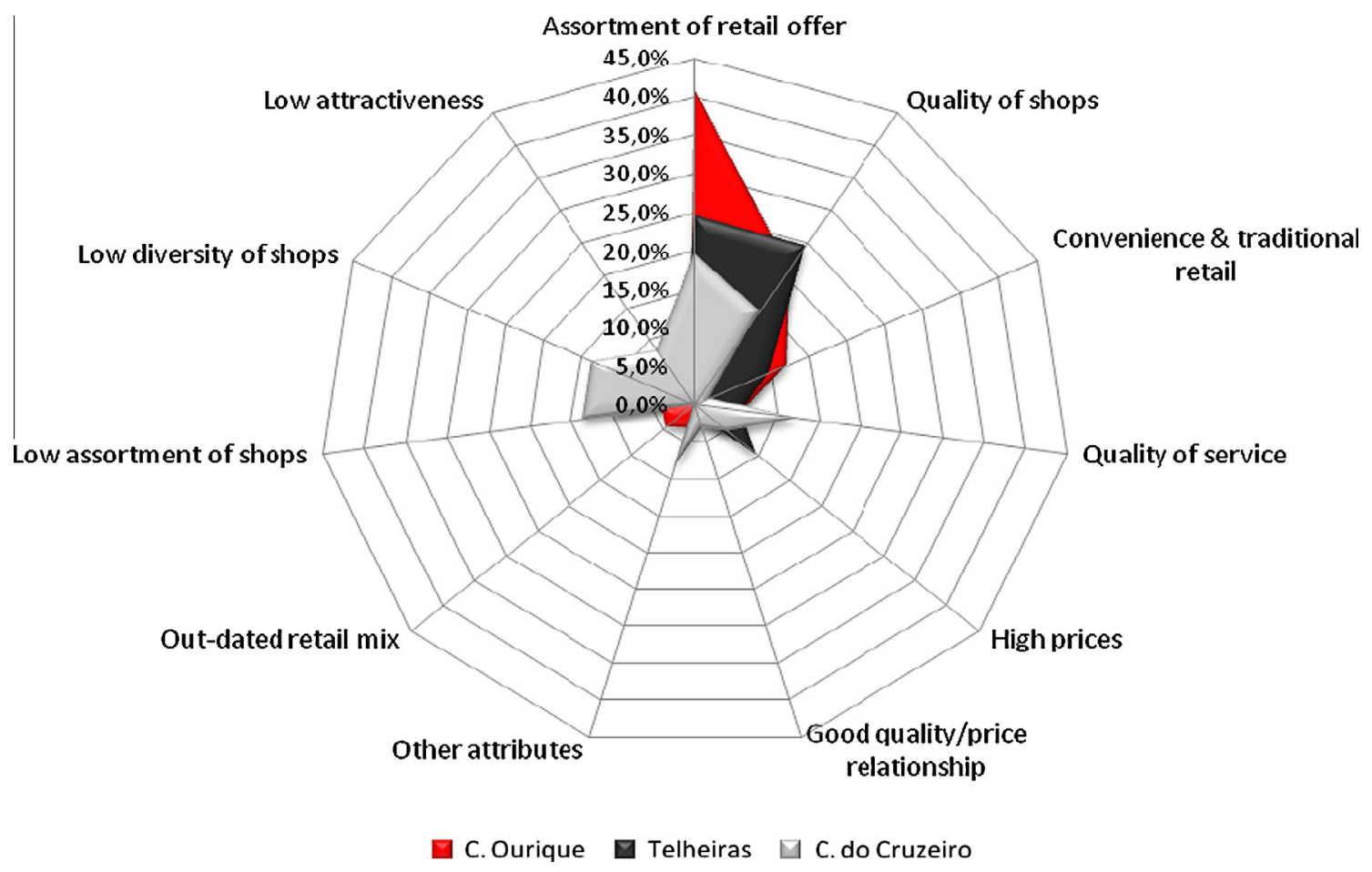

Fig. 6. Consumers' perceptions of neighborhood shopping districts. Source: Cachinho (2012). 
Another dimension that is relevant to consumerscapes concerns the way the respondents spontaneously describe the characteristics of the offer in their shopping areas. In being appropriated by the consumers as the fountainhead of their resources, and called up so as to bring about their life projects, the images they build tend to emphasize their own potentialities and constraints and reflect their own levels of satisfaction as individuals-consumers. Fig. 6 briefly illustrates these fields.

Broadly speaking, it may be said that retail offer representations complement the image formed of the neighborhoods' general characteristics that were discussed earlier on. Apart from the specific features mainly when speaking about the performances of distinct attributes, in all the shopping areas the assortment and the quality of the retail offer (or the serious lack of it) indelibly marked the respondents' perceptions. In fact, other attributes are mentioned such as the prices of goods, the modern attractive nature of the shops, the quality of the service and the friendliness of the shopkeepers, but these variables are only present in the minds of a very small number of respondents.

Taking into account the relationship between the positive and negative factors, the Campo de Ourique neighborhood has a less fragile retail and services mix than the other two and consequently, it is where the consumers may more easily find the cultural resources needed to fulfill their life projects that are directly dependent on consumption. In Telheiras and Colinas do Cruzeiro, where most of the attributes only reach a modest performance, the eminently residential nature of these two districts is revealed. It is also a good indicator that the lack in the retail and personal services offer will have to be attended to so that the retail facilities and services will become part of the mindset of most of the individuals-consumers. When interpreted in the light of the CCT, it may be said that the cultural resources made available by the shopkeepers are clearly not enough to bear any significant influence on either people's shopping experiences or on neighborhood identities.

Finally, the third question has to do with the shortcomings identified in the neighborhoods by the respondents. From the point of view of resilience, this question is extremely important because the deficiencies are portrayed in a set of frailties concerning the cultural resources which the individuals-consumers need to have at their disposal if they are to carry out their personal and collective projects. By having the shopkeepers bridge this gap in terms of retail and service venues, or getting the public authorities to attend to public space and other urban amenities, like parking facilities, public transports and security services, the population's satisfaction will reflect a distinct improvement and naturally, this will be reflected upon the neighborhood's enhanced performance as a leisure and shopping space. This is because the better equipped they are with the resources needed by consumers, the easier it will be for shopping districts to gain the loyalty of their consumers and more efficiently resist the competition brought about by the new shopping polarities anchored in the large-scale shopping malls.

Fig. 7 shows the shortcomings mentioned by the respondents in the survey. Again, they are divided up into different categories with distinct features according to each of the three neighborhoods in the study. In a brief analysis of the weaknesses, it is important to start by saying that for a significant part of the population answering the survey, the neighborhoods offer them all the resources they need for carrying out their projects and they feel quite happy about the retail offer available to them and about the neighborhood's atmosphere. They did not single out any type of need. Nevertheless, the majority of the respondents said they were not satisfied about several things and pointed out various shortcomings related not only to the retail offer but also to the amenities present in the public space. In the Campo de Ourique neighborhood, demands were for better spaces and leisure-time and cultural activities, more parking facilities, cleaner public thoroughfares, a wider assortment of shops and an improvement in public transports. In the Telheiras neighborhood, which apparently did not have any problems of an urban nature, the respondents demanded first and foremost, a wider assortment in the retail offer and access to more activities and leisure-time and cultural spaces. On the other hand, the respondents in Colinas do Cruzeiro mentioned better parking facilities and a wider assortment in the retail offer in first place, and they wanted public gardens/parks to be built as well as other spaces reserved for leisure-time activities.

In short, the consumerscapes of Campo de Ourique, Telheiras and Colinas do Cruzeiro made it clear that the consumers tend to appropriate the neighborhoods as centers of material and intangible resources through which they build their own personal and collective life projects. These resources are made available by a number of different institutions and private and public spaces. Particularly relevant among such resources are, on the one hand, the shopkeepers and shopping and consumer places through the offer and cultural environments they provide. On the other hand, they also include the public authorities and the neighborhood environments (both physical and social), with special reference to public spaces and the diversity of activities undertaken in them. The resources provided by shopkeepers and the public authorities are interpreted by consumers, thereby activating their own operant resources. Actually, because they are inanimate and do not have either a function or a meaning, such resources only become valuable when consumers activate their own economic, social and ideological resources, and enlist them in their performances (Arnould, 2005; Arnould \& Price, 2000).

The appropriation of shopping districts is achieved by consumers first on a material basis. Valorizing the material assets is foremost when both the neighborhood's potentialities and its weaknesses are evaluated. It shapes the description that the respondents make of the shopping facilities and environmental amenities on offer in their neighborhoods, as does the absence of resources demanded by consumers according to their needs. Included in such demands, for example, is the importance awarded questions about mobility or circulation (parking, accessibility, public transports), safety or the public space and, when concerned with the shopping areas, references about the lack of variety in shopping assortment, the offer of goods and services, and spaces conducive to leisure and socializing.

In the meantime, appropriation is also effected at the intangible level of symbols and signs which are interpreted by the consumers according to their cultural capital or operant resources, to use the terms of Vargo and Lusch (2004). This mode of appropriation, linked with the consumer's mindscapes, and which we shall call cultural because it activates consumers' skills, knowledge, values and ideologies, also affects the evaluation of the built environment and the retail mix. When asked to give reasons for their representations or clarify the meaning of the words they had used to describe their neighborhood, for example, "this place has a pleasant environment", or "this place is interesting to be in with my family and friends", the respondents tended to mention qualities that are directly connected with values and life-styles. It is this sense that we may interpret the references that are often made, for example, to social status, prestige and distinction of neighborhoods, the value they attach to local shops and convenience facilities, the friendliness of shopkeepers or the opportunities for socializing afforded by public space and pavement cafés, as well as the way these kinds of facilities and amenities help them to live significant experiences in the neighborhood, perform their social roles and feel good about their lives.

Interpreting the neighborhoods and shopping areas as a supplier of resources and looking at their relationship with the 


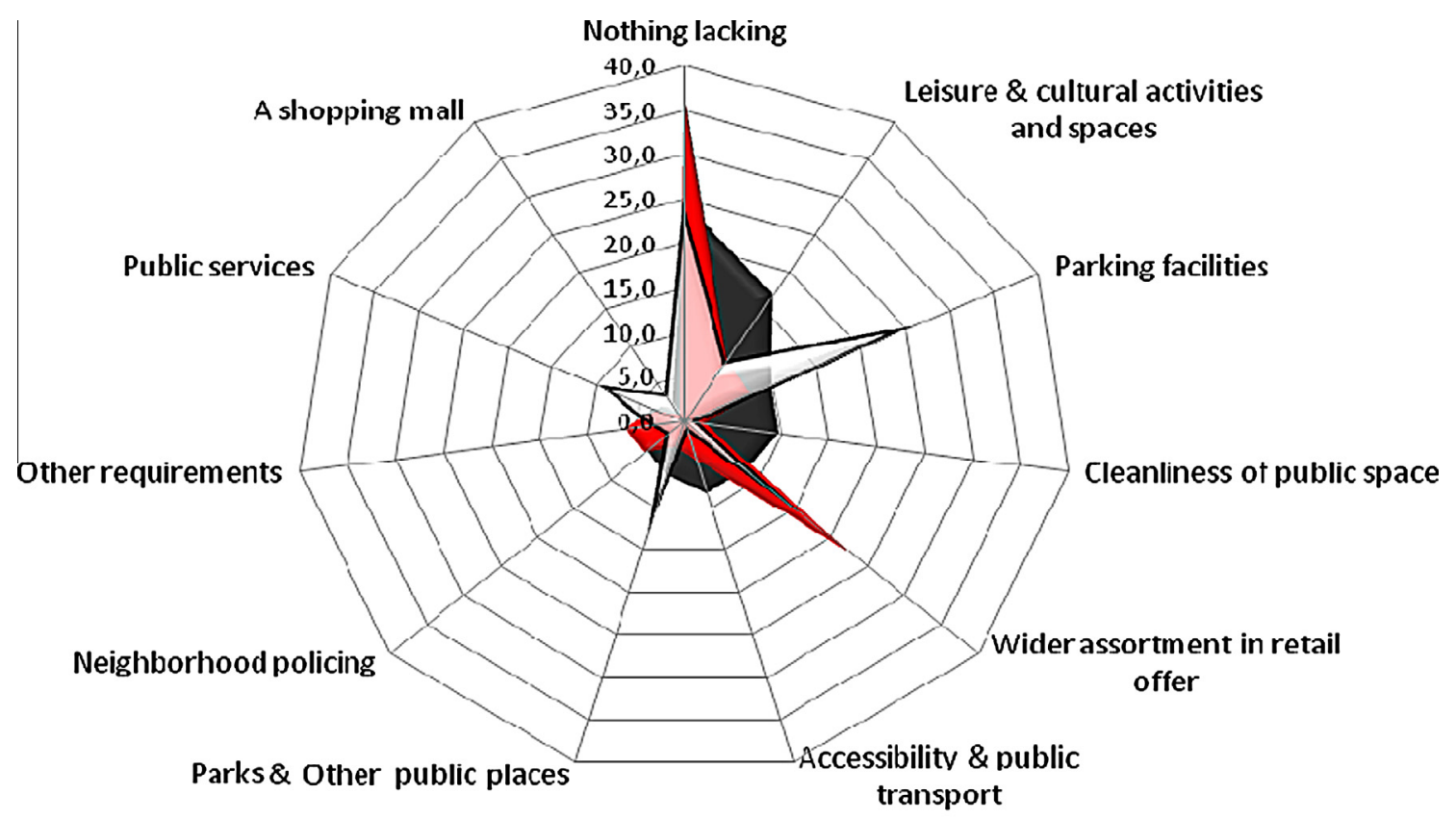

घ Campo de Ourique $\square$ Telheiras $\square$ Colinas do Cruzeiro

Fig. 7. Consumers' perceptions of what is needed in the neighborhoods. Source: Cachinho (2012).

residents' life projects, is particularly relevant when considering the demand for chances to consume. In calling for a greater diversity of supply, more leisure and culture spaces, bringing in some brand stores or even a shopping mall, the consumers are saying that the resources they currently have on offer in their neighborhood are far from satisfying their consumer needs dictated by their life-styles. The content analysis of information gathered by means of the in-depth interviews allowed us to conclude that a good part of the resources that were demanded by the consumers in their neighborhoods, above all in Telheiras and Colinas do Cruzeiro, had a strong symbolic note to them which says a lot about their users' life-styles and identities.

Empirical research shows that as providers of convenience resources for consumers' daily lives, the three neighborhoods fail to fully satisfy the needs of most of the people taking part in the survey. From the point of view of retailing, the weakness that is patent mainly as regards assortment and the quality of the offer, have led many consumers to look beyond their neighborhood for the experiences nourishing their personal and collective life projects based on consumption. In this context, retailers and service providers, individually or in partnership with the public authorities and other stakeholders, have a lot of room in which to maneuver and in doing so they can provide these neighborhoods with the retail venues, environments and amenities that may respond to the daily needs of different kinds of consumers. By reducing these constraints, businesses will be doing a lot to substantially improve their clients' loyalty; they will also raise the consumers' levels of satisfaction quite considerably and cause them to identify closer with their neighborhood and its shopping districts. This is because the better equipped the neighborhood is with resources that lead to generating consumers' goal-relevant experiences, the more it will improve its resilience.

With a view to planning the retail systems and the public policies that provide a framework for them, the consumerscapes tell us that the public authorities should prioritize their attention in two directions: (i) they should come up with policy proposals and tools that enable retailers to change; and (ii) they should preserve the assortment, namely in terms of formats, kinds of shopkeepers and shopping areas. While policy measures should act against inertia and stimulate retailers' pro-activeness and adaptability, qualities that are intrinsically linked to their competitiveness, the diversity of retail concepts and shopping centers should be preserved, thus ensuring that the consumers are given the possibility of choice, including the most underprivileged consumers and those with limited mobility. By steering its mediating activity between these two pillars, public authorities will assuredly be helping to reduce weaknesses in the retail systems and improving their long term levels of resilience.

If they are monitored on a regular basis by the public authorities, consumerscapes may be a powerful tool for the planning and governance of the city at local scale. Due to their attributes, they can help stakeholders to implement a policy of proximity, strengthening the livability of places, exerting real effects on the community's quality of life and the sustainability of the city as a whole. Actually, livability is a complex and multidimensional concept, shaped by a wide range of variables interconnecting the spheres of the economy, the environment and social well-being. But, at the same time, it is acknowledged that livability is essentially local in character, and deeply reliant on the quality of the physical and built environment, the functional effectiveness of places, and the social ambience, including the public safety of places (Knox \& Mayer, 2009). Thus, by incorporating consumerscapes in the design and management of the neighborhoods, local planners and policymakers can adapt the amenities of places to people's real needs. By working in partnership with people living in the neighborhoods, stakeholders are creating and maintaining a sense of place and a sense of community. The environment becomes more enjoyable and inviting; the opportunities for routine encounters, shared experiences and socializing increase, and people being more satisfied with local facilities show more willingness to put their neighborhood first, feeding its resilience and sustainability. 


\section{Concluding remarks}

Change has always affected urban retail systems although in the last few decades the pace and scope at which this change has occurred has been extremely fast. Rapid change has caused imbalances in many cities as they have ceased to respond with the same degree of efficiency to the needs of different groups of consumers. In departing from the idea that retailing constitutes a vital element in urban sustainability and that public policies geared towards the sector may help to develop this equilibrium, this article has sought to show how consumerscapes may be called upon to reduce the frailties in shopping areas and improve their levels of resilience. In order to do so, we have looked at the matter through the lens of the Consumer Culture Theory (CCT).

In resorting to consumerscapes and the CCT when assessing the vitality of retail areas and their levels of resilience, we have based ourselves mainly on two ideas. The first idea revolves around the nature of the changes affecting the retail systems today and challenging their equilibrium in terms of diversity and the answers that are needed by different kinds of consumers. Different authors have demonstrated how changes in the urban retailing reflect a reorientation of the strategies carried out by pro-active shopkeepers. These have clearly moved from producers to the consumers. They have also shown how consumption in the contemporary city has been transformed into a key element in building people's identity and in fulfilling their personal or collective life projects. In this context and as specified in the CCT, it seems to us to be pertinent to look at retailers and stores as the fountainhead of resources that are placed at the service of consumers' projects and goals. It is in this condition that firms, at least the most pro-active ones, tend to position themselves in the market and improve their competitiveness. By offering the consumers the resources they need to meet their needs and reach their goals, retailers and serviceproviders raise the consumers' levels of satisfaction and improve their firms' performances. The second idea is based on applying the concept of resilience to urban retail systems and the role that consumers play in its assessment. In being seen as the ability which retail venues have to adapt to changing environments that challenge the retail system's equilibrium without failing to perform its functions in a sustainable way, that is, as a dynamic and evolutionary process, through a consumer-centric perspective of stores and shopping districts we can better understand the system's dynamics and take measure to minimize the impacts of change. The analysis of consumerscapes and the myriad of motivating factors that they explain not only help retailers to re-define their strategies in order to provide the resources consumers need, but also inform the public authorities about the frailties of the retail venues and shopping districts, and as a result, help them to design more suitable policy proposals and instruments.

Finally, it can be inferred from research that consumerscapes may also play an important role in the governance of the city and in the management of places committed to the resilience of shopping districts, the livability of neighborhoods and urban sustainability. In expressing the potentials and the constraints of neighborhoods in relation to the different aspects of livability, through reviewing them, stakeholders are able to rethink their strategies destined to reduce the weaknesses of places regarding the resources provided to residents as well as make their action more effective. By resorting to a policy of proximity and community involvement, the weaknesses are a challenge to be overcome but they are also an opportunity for stakeholders (public and private) to rethink their actions and build more resilient and sustainable communities.

Our research has served to broaden the conceptual framework of the CCT that was developed by Arnould (2005) for shops in shopping districts in order to measure their weaknesses and improve the urban retail systems' levels of resilience. This change in scale raises some important challenges that require further research. The answer to these questions is far from being clear. However, this article hopes to have shed some light on the subject and more in particular, to have shown the interest that CCT and consumerscapes represent in the assessment of the resilience of neighborhood shopping districts.

\section{References}

Amendola, G. (2000). La Ciudad Postmoderna: Magia y Miedo de la Metrópolis Contemporánea. Madrid: Celeste Ediciones.

Arnould, E. (2005). Animating the big middle. Journal of Retailing, 81(2), 89-96.

Arnould, E. (2007). Consuming experience. Retrospects and prospects. In A. Carù \& B. Cova (Eds.), Consuming experience (pp. 185-194). Oxon: Routledge.

Arnould, E., \& Price, L. (2000). Authenticating acts and authoritative performances: Questing for self and community. In S. Ratneshwar, D. Glen Mick, \& C. Huffman (Eds.), The why of consumption (pp. 140-163). London: Routledge.

Arnould, E., \& Thompson, C. (2005). Consumer culture theory (CCT): Twenty years of research. Journal of Consumer Research, 31(March), 868-883.

Bäckström, K. (2006). Understanding recreational shopping: A new approach International Review of Retail, Distribution and Consumer Research, 16(2), $143-158$.

Balsas, C., Kotval, Z., \& Mullin, J. (2004). City center revitalization in the USA, principles, techniques and case studies. In G. Moras et al. (Eds.), L'Approccio Integrato Alla Qualificazione Urbana (pp. 209-218). Celide, Turim: Modelli e Strategie di Urbanistica Commerciale.

Barata Salgueiro, T. \& Cachinho, H. (2009). As relações cidade-comércio: dinâmicas de evolução e modelos interpretativos. In C. Carreras, S. Pacheco, \& (org.) (Eds.), Cidade e Comércio: a rua comercial na perspectiva internacional (pp. 9-39). Rio de Janeiro: Armazém das Letras.

Barata-Salgueiro, T. (2011). The resilience of urban retail areas. In T. Barata Salgueiro \& H. Cachinho (Eds.), Retail planning for the resilient city: Consumption and urban regeneration (pp. 19-44). Lisbon: CEG.

Barata-Salgueiro, T., Cachinho, H., \& Rocha, F. J. (2007). Avaliação dos impactos dos centros comerciais na cidade de Évora. Lisbon: FLUL.

Baudrillard, J. (1970). La société de consommation. Paris: Denoël.

Baudrillard, J. (1975). Le miroir de la production, ou l'illusion critique du matérialisme historique. Paris: Galilée.

Berry, B. (1963). Commercial structure and commercial blight: Retail patterns and progresses in the city of Chicago. University of Chicago. Research paper, no. 85.

Beyard, M. D., Pawlukiewicz, M., \& Bond, A. (2003). Ten principles for rebuilding neighborhood retail. Washington, DC: Urban Land Institute.

Bohl, C. (2002). Place making: Developing town centers, main streets, and urban villages. Washington, DC: Urban land Institute.

Borchert, J. G. (1988). Planning for retail change in the Netherlands. Built Environment, 14(1), 22-37.

Borchert, J. G. (1998). Spatial dynamics of retail structure and the venerable retail hierarchy, GeoJournal, 45, 327-336.

Borghini, S., Diamond, N., Kozinets, R., McGrath, M., Muñiz, A., \& Sherry, J. (2009). Why are themed branstores so powerful? Retail brand ideology at American girl place. Journal of Retailing, 85(3), 363-375.

Bromley, R., \& Thomas, C. (1993). The retail revolution, the carless shopper and disadvantage. Transactions of Institute of British Geographers, 18(2), 222-236.

Bromley, R., \& Thomas, C. (1995). Small town shopping centre decline: Dependence and inconvenience for the disadvantaged. The International Review of Retail Distribution and Consumer Research, 5, 433-456.

Cachinho, H. (2002). O Comércio Retalhista Português: Pós-modernidade, Consumidores e Espaço. Lisbon: GEPE.

Cachinho, H. (2006). Consumactor: da condição do indivíduo na cidade pósmoderna. Finisterra, 81, 33-56.

Cachinho, H., \& Barata-Salgueiro, T. (in press). O comércio urbano em tempos de turbulência: Elementos para avaliar as vulnerabilidades e níveis de resiliência. In Paper presented to the XII Iberian congress of Geography, Porto.

Cachinho, H. (2011). Urban retail dinamics: From shopping spaces to consumer places. In H. Cachinho \& T. Barata Salgueiro (Eds.), Retail planning for the resilient city: Consumption and urban regeneration (pp. 147-168). Lisbon: CEG.

Clarke, D. (2003). The consumer society and the postmodern city. London: Routledge.

Claxton, R., \& Siora, G. (2008). Retail-led regeneration: Why it matters to our communities? London: DTZ Consulting, pp. 1-52.

Coleman, P. (2006). Shopping environments: Evolution, planning and design. Oxford: Architectural Press.

Crawford, M. (1992). The world in a shopping mall. In M. Sorkin (Ed.), Variations on a theme park (pp. 3-30). New York: Hill and Wang.

Debenedetti, A., Mencarelli, R., Debenedetti, S. (2011). Une approche CCT de l'expérience muséale chez les jeunes adultes : le modèle de Falk. <http:// halshs.archives-ouvertes.fr/halshs-00635794>.

Din, R. (2000). New retail. London: Conran Octopus.

Dixon, T. (2005). The role of retailing in urban regeneration. Local Economy, 20(2), $168-182$.

Dupuis, M. (1988). Distribution: la nouvelle donne. Paris: Les Éditions d'Organisation. 
Erkip, F. (2003). The shopping mall as an emergent public space in Turkey. Environment and Planning A, 35, 1073-1093.

Featherstone, M. (1991). Consumer culture \& postmodernism. London: Sage.

Firat, A. F., \& Dholakia, N. (1998). Consuming people. From political economy to theaters of consumption. London: Routledge.

Firat, A. F., \& Venkatesh, A. (1993). Postmodernity: The age of marketing. International Journal on Research in Marketing, 10(3), 227-249.

Foord, J., Bowlby, S., \& Tillsley, C. (1996). The changing place of retailer-supplier relations in British retailing. In N. Wrigley \& M. Lowe (Eds.), Retail, consumption and capital. Towards the new retail geography (pp. 68-89). Essex: Longman.

Gardner, C., \& Sheppard, J. (1989). Consuming passion. The rise of retail culture. London: Unwin Hyman.

Giese, J., \& Cote, J. (2002). Defining consumer satisfaction. Academy of Marketing Science Review, 2000(1). http://www.amsreview.org/articles/ giese01-2000.pdf.

Gómez, M. I., McLaughlin, E. W., \& Wittink, D. R. (2004). Customer satisfaction and retail sales performance: An empirical investigation. Journal of Retailing, 80, 265-278.

Goodman, R., \& Coote, M. (2007). Sustainable urban form and the shopping centre: An investigation of activity centres in Melbourne's growth areas. Urban Policy and Research, 25(1), 39-61.

Goss, J. (1993). The 'magic of the mall': An analysis of form, function, and meaning in the contemporary retail built environment. Annals of the Association of American Geographers, 83(1), 392-403.

Goss, J. (1995). We know who you are and we know where you live: The instrumental rationality of geodemographic systems. Economic Geography, 71(2), 171-198.

Guy, C. (2007). Planning for retail development: A critical view of the British experience. London: Routledge.

Haytko, D., \& Baker, J. (2004). It's all at the mall. Exploring adolescent girls' experiences. Journal of Retailing, 80, 67-83.

Hetzel, P. (2002). Planète Conso: Marketing expérientiel et nouveaux univers de consommation. Paris: Éditions d'Organisation.

Holt, D. (2002). Why do brands cause trouble? A dialectical theory of consumer culture and branding. Journal of Consumer Research, 29(June), 70-90.

Jayne, M. (2006). Cities and consumption. London: Routledge.

Knox, P. L., \& Mayer, H. (2009). Small town sustainability. Economic, social, and environmental innovation. Basel: Birkhauser.

Kozinets, R. V., Sherry, J. F., DeBerry-Spence, B., Duhachek, A., Nuttavuthisit, K., \& Storm, D. (2002). Themed flagship brand stores in the new millennium: Theory, practice, prospects. Journal of Retailing, 78, 17-29.

Lipovetsky, G. (2006). Le Bonheur paradoxal: Essai sur la société d'hyperconsommation. Paris: Gallimard.

Littlefield, D. (2009). Liverpool one: Remaking a city centre. Chichester: John Wiley \& Sons Ltd..

Martin, R. L. (2011). Regional economic resilience, hysteresis and recessionary shocks. Journal of Economic Geography, 12(1), 1-32.

Marx, K. (1973). Production, consumption, distribution, exchange (circulation). In D. B. Clarke, M. A. Doel, \& K. M. L. Housiaux (Eds.), (2003) The consumption reader (pp. 251-254). London: Routledge (Extracted from Grundrisse: Foundations of the Critique of Political Economy, Pelican Books, London).

Meir, A., \& Marcus, M. (1983). A commercial-blight perspective on metropolitan commercial structure. Canadian Geographer, 27(4), 370-375.

Mermet, G. (1996). Tendances 1996: Le nouveau consommateur. Paris: Larousse.

Mermet, G. (1997). Tendances 1998: Les nouveaux consommateurs. Paris: Larousse.

Messerlin, P. (1982). La Révolution Commerciale. Paris: Bonnel Editions.

Mikunda, C. (2006). Brand lands, hot spots, and cool spaces: Welcome to the third place and the total marketing experience. London: Kogan Page.
Miles, S. (2010). Spaces for consumption. Pleasure and placelessness in the postindustrial city. London: Sage Publications.

Mitchell, A., \& Kirkup, M. (2003). Retail development and urban regeneration: A case study of Castle Vale. International Journal of Retail and Distribution Management, 31(9), 451-458.

Morace, F., \& (org.) (2009). The generations as creative enterprises. Milan: Libri Scheiwiller. Consum-authors.

Morace, F. (1990). Controtendenze. Una nuova cultura del consumo. Milan: Domus Academy Edizioni.

Office of the Deputy Prime Minister (2005). Planning policy statement 6: Planning for town centres. London: TSO.

Office of the Deputy Prime Minister (2009). Planning policy statement 4: Planning for sustainable economic growth. London: TSO.

Oldenburg, R. (Ed.). (2001). Celebrating the third place. . Inspiring stories about the "Great Good Places" at the heart of our communities. New York: Marlowe \& Company.

Padilla, Ch., \& Eastlick, M. A. (2009). Exploring urban retailing and CBD revitalization strategies. International Journal of Retail $\mathcal{E}$ Distribution Management, 37(1), 7-23.

Pine, B. J., \& Gilmore, J. H. (1999). The experience economy. Work is theatre and every business a stage. Boston: Harvard Business School Press.

Ravenscroft, N. (2000). The vitality and viability of town centres. Urban Studies, 37(13), 2533-2549.

Robertson, K. (1997). Downtown retail revitalization: A review of American development strategies. Planning Perspectives, 12, 383-401.

Sennett, R. (1977). The fall of public man. Cambridge: Cambridge University Press.

Smith, J., Gourgott, C., \& Devine, P. (2001). The great good gym. In R. Oldenburg (Ed.), Celebrating the third place. Inspiring stories about the "Great Good Places" at the heart of our communities (pp. 131-142). New York: Marlowe \& Company.

Tallon, A. (2010). Urban regeneration in the UK. London: Routledge.

Thomas, C., \& Bromley, R. (2003). Retail revitalization and small town centres: The contribution of shopping linkages. Applied Geography, 23, 47-71.

Urban-Net (2010). Research anthology 2010. Edinburgh: SNIFFER

Vargo, S., \& Lusch, R. (2004). Evolving to a new dominant logic for marketing. Journal of Marketing, 68(June), 1-17.

Varman, R., \& Belk, R. (2011). Consuming postcolonial shopping malls. Journal of Marketing Management, 1-23.

Westlake, T. (1993). The disadvantaged consumer: Problems and policies. In R Bromley \& C. Thomas (Eds.), Retail change: Contemporary issues (pp. 172-191) London: UCL Press.

Williams, C. (1997). Consumer services and economic development. London and New York: Routledge.

Williams, P., \& Hubbard, P. (2001). Who is disadvantaged? Retail change and social exclusion. The International Review of Retail, Distribution and Consumer Research, 11(3), 267-286.

Wood, S., Lowe, M., \& Wrigley, N. (2006). Life after PPG6 - Recent UK food retailer responses to planning regulation tightening. The International Review of Retail, Distribution and Consumer Research, 16(1), 23-41.

Woodruffe-Burton, H., \& Wakenshaw, S. (2011). Revisiting experiential values of shopping: consumers' self and identity. Marketing Intelligence E Planning, 29(1), 69-85.

Wrigley, N., \& Dolega, L. (2011). Resilience, fragility, and adaptation: New evidence on the performance of UK high streets during global economic crisis and its policy implications. Environment and Planning A, 43(10), 2337-2363.

Wrigley, N., \& Lowe, M. (2002). Reading retail. A geographical perspective on retailing and consumption spaces. London: Arnold.

Zentes, J., \& Schwarz-Zanetti, W. (1988). Planning for retail change in west Germany. Built Environment, 14(1), 38-46. 